\title{
The Applied Research on the Micro-Course Development of Fine Arts Skills Based on the Cloud Platform
}

\author{
Jie $\mathrm{Fu}$ \\ Zaozhuang College \\ Bei'an Road, Zaozhuang, Shandong, China
}

\begin{abstract}
With the popularity of the internet and extensive application of modern educational technology, mobile study and online study become a learning fashion. In this study, the blended learning mode based on the micro-course is constructed to widely promote the teaching reform of fine arts skill course represented by the fine arts elementary courses and manual training. In the specific teaching, the author attempts the "micro-case" teaching, makes innovations on the classroom teaching mode, and improves teaching quality.
\end{abstract}

Keywords-Micro-course; preschool education; blended learning; fine arts skill course; Micro-courses

\section{INTRODUCTION}

Ministry of Education studied and formulated the "13th Five-year Plan” of Educational Informationization, implying that the educational informationization insists in promoting the core idea of deep integration between information technology and educational teaching. With the constant maturity and development of technology application, cloud classroom and big data will walk into the classroom and really overturn our traditional classroom. There is no limitation of time and place in study. Lifelong learning and mobile learning will become realistic.

In addition, people are able to use the infinite resources to study at any time anywhere. The advantages of micro-course are corresponding to the instant fragmented study. It is a trend for Chinese young people to use small time slots for online independent study after lots of educational entrepreneurs throw themselves in e-learning. It is predicted that online study users in the end of 2017 has been increased to more than one times from 98 million in 2016 to 188 million. According to the report of iiMedia, this figure in China would be up to 292 million in 2018. Another report issued by Alibaba predicted that in the end of 2017, the online study market would reach 50 billion RMB. Chen Li, a vice president of Beijing Normal University, said, "Nowadays, people prefer to individualized study, especially for a flexible way of study."

This study is based on the physical truth of fine arts skill classroom of preschool education major to investigate actual demands of students, to study the micro-course design strategy of fine arts skill course, to construct the design and application model of the fine arts skill micro-course, and to form the operable process. On the basis of practice application and effect evaluation, it is constantly corrected and perfected to provide the theoretical and practice basis for fine arts skill course teaching in this major. At the same time, by aiming at actual problems in fine arts skill classroom, the strategy of solving these problems is founded out to finally achieve a goal to improve teaching effectiveness of fine arts course, to explore the new approach to improve the teaching effect of fine arts skill course, and to explore strategy and method of using the micro-course into the high college teaching effectively.

\section{MICRO-COURSES}

It is widely believed that it doesn't mean to add your average asynchronous e-learning course on a phone, but aims to provide more performance support. Both brevity and wit are the soul of mobile. I am glad to treat mobile as the supplement of formal learning to motivate knowledge, spread practice, contextualize learning, and capture performance. However, when we go to the "gray" area of the so-called micro-courses, I think a complete course must motivate introduction of relevant knowledge: one is to guide the performance model, one is to display the cases in the context, and another one is the practice chance in another context. At last, it is necessary to conduct reflection after practice and summarize learning experience.

If it is lower than this value, information will be minimized when learners start it at a moment, so that learners pass through the direct point. This is the performance support. Or learners have the learning motivation and acceptance capacity. This means information renewal, instead of a new skill, so I don't think it is a course.

On the other hand, they just reflect on things that they are doing to "adjust" another method with meaningfulness. Or it is a regular mini-presentation or small practice can treat with the same thing in a different way. Perhaps, it is ok if it is distributed learning, instead of a mini-course.

\section{SUMMARY AND REFLECTION ON CLASSROOM TEACHING OF FINE ARTS SKILL COURSE}

\section{A. Teaching gives priority to collective instruction}

Teaching gives priority to collective instruction, so it can't effectively promote development of each student in accordance with feature of each student. The learning difference of students is caused by different personality, interest, learning capacity and learning foundation. The current teaching mode can't greatly satisfy internal learning demands of students with different level of learning. It is embodied in 45 min of a class. 
When teachers prepare lessons, they firstly should give considerations to acceptance of students. It is hard to consider students with good learning degree and students with poor learning degree, thus some students may be "yearning for more knowledge", but some students think it is too difficult to learn it. According to the humanized teaching principle, this is a great malpractice.

\section{B. New educational elements including network and mobile phone can't be effectively used.}

Occurrence of network enables network education resources to be shared, accompanying by renewal and development of teachers' study, preparation and teaching through the network. For difficult and key points, the better reference can be provided. In this way, this will enhance preparation instruction level and improve exchange, while sharing. In terms of students, mobile phone and iPad enable them to browse online resources at any time anywhere, so as to realize the effective integration between the high-quality network education resources and classroom teaching. At present, teachers consciously use the network education resources in course teaching process and take advantage of the network to look up relevant data in the preparation process, but the sharing and communication between teachers are insufficient. In this way, the high-quality network education resources can't be fully utilized. According to the students' learning state, if the open network teaching is used in the class process, classroom teaching may be not greatly grasped. Students "play with" the network, instead of study. Similarly, if students are allowed to use mobile phone in the classroom teaching process, it is hard to safeguard how many students will use it for study, instead of playing. Therefore, how can we use the excellent educational resources in a better way? How can we adapt to the open classroom requirements in today's society?

\section{The consciousness of integrating the new education technology into the classroom is insufficient.}

In addition, the level is limited, thus good network resources can't be effectively used. People can't attempt the teaching reform, let alone improvement on the classroom teaching quality. It is easy to result in the lagging teaching state of "acting blindly". This is unmatched with the developed network technology in current days and can't conform to the teaching quality requirements. At present, Zaozhuang College is matched with the standard multimedia teaching. Teachers use the courseware+ explanation or demonstration+ explanation mode in the instruction process or even provide a mobile capture bag in front of a classroom, thus mobile learning terminal and network can't be fully used in teaching process.

\section{Students are young, so they don't have the definite learning objectives.}

They don't cultivate a good learning habit and have no autonomy in study. Both 45 min classroom teaching process and traditional teaching mode give considerations to develop learning subjectivity of students, but the actual instruction process has the poor effect. The research objects in this study determine the more difficulties in instruction, due to age features, learning status and thought features.
The above-mentioned statements refer to ubiquitous problems in the grade 5 preschool education. The study in this paper will fundamentally provide a new attempt idea to solve these problems, because micro-course enables teachers to reduce instruction time and meet the teaching objectives, thus teachers will have enough time to do the effective communication between students or communication between teachers and students. At the same time, application of the diversified learning modes will be good for promoting the creative capacity of students, so as to provide the specific teaching implementation idea, thus micro-course will be greatly used to the actual teaching to enrich the teaching means, make innovations on the teaching mode, and improve learning interest and efficiency, so as to make innovations on the classroom teaching mode and improve the classroom teaching level to a new degree.

\section{Micro-Course Production ANd Applied Research OF MICRO-COURSE}

\section{A. Micro-course production}

1) Basic hardware equipment

An office (quiet and good ray of light); a laptop with builtin or external camera; two Sony mobile phones (with lampstand); a wireless headset.

\section{2) Main software configuration}

Screen recording software Camtasia Studio 8 Chinese cracked version.

\section{3) Main software configuration}

As shown in the figure, production of micro-course video is basically divided into four steps:

Content confirmation $\rightarrow$ video design $\rightarrow$ video recording $\rightarrow$ post production

a) Content confirmation: Micro-course aims to reveal the refined and small content with the short time. The explanation should have pertinence and innovation to attract learners. Therefore, this process is very important.

b) Video design: Micro-video design should fully reveal "micro", which means fragmentation. For this reason, it can adapt to the requirements of mobile learning. It is necessary to design from content presentation, language and body language and environment. Only the comprehensive and considerable design can it guarantee the timeliness in the video recording process.

c) Video recording: The environmental requirements of video recording need a quiet environment, sufficient ray of light and necessary hardware. Meanwhile, it is necessary to master some recording skills. The micro-course video process actually is the process to reveal the teaching design. It not only should value the external recording effect, but also should contain the core contents, including more important specific explanation of teaching design and teaching contents.

d) Post production: Camtasia Studio 9 is used for postproduction. For example, a title is added. A good title will successfully attract interest of speculators. Video background should be good enough to stand out the video content. In 
addition, background music is also very important, thus speculators will feel joyful, while studying, so as to improve efficiency. Text editing and video must be equipped with the proper texts.

\section{The ApPliEd ReseARCH OF Micro-COURSE}

It is necessary to explore and construct the design model and operable process of micro-course in the fine arts skill course. Relevant resources and data collected in early-stage investigation are analyzed to construct the micro-course design model and operable process targeted at the fine arts skill course. Moreover, the model design has the targeted micro-course case. The basic course process designed in this study is shown as follows:

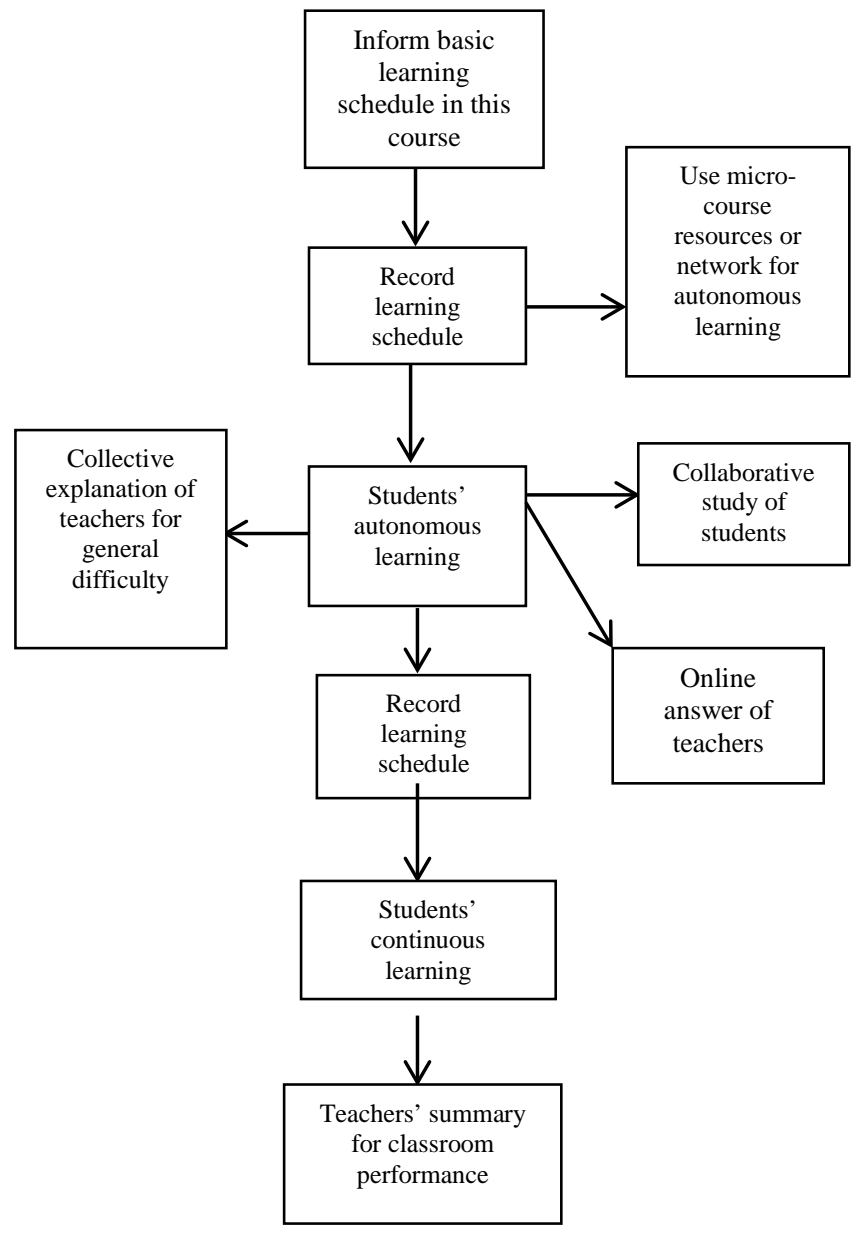

Fig. 1 The course process design

Micro-course case design and experimental demonstration: According to the micro-course design and application mode, different types of micro-course cases are designed. The case applied research and post-survey evaluation of micro-course in teaching are used for further improvement and perfection, thus design, application mode and operable process will have feasibility, providing the experimental foundation and practice basis for the applied prospect demonstration of micro-course in the educational field.

Exploration on the new approach to improve teaching effect of fine arts skill course and effective utilization of micro-course are used to college teaching. With the factual basis of investigation analysis and experimental demonstration, the micro-course effect in the application conducts the postanalysis, so as to summarize the advantages and status of micro-course in teaching and demonstrate the feasibility and promotion value of the micro-course in the fine arts skill course teaching. At the same time, the micro-course problems in the implementation process and limitation of fine arts skill course teaching are deeply analyzed to propose the countermeasures on improvement and put forward the valuable opinions on the transfer application of micro-course in other course field, so as to explore the new approach in the micro-course application classroom. Conclusion/Summary

\section{CONCLUSION}

In this paper, the author focuses on the applied research of micro-course in the classroom teaching. The research direction is targeted at in-class, after-school and students' review. The scattered time is advocated to be used to realize the fragmented study. For students with the main task of study. In-class is the important learning time for their study. It is extremely important for students' study by effectively use the classroom. As a result, it is very important to study micro-course for the classroom teaching. Furthermore, exploring the application strategy of micro-course and application effect of fine arts skill classroom is another innovative task.

\section{REFERENCES}

[1] Liu Feng'e, the Blended Teaching Mode Study Based on the Microcourse[J], English Square, 2017(1): 72-73.

[2] Wang Tongju, the Construction and Practice of the "Micro-course Guiding” Teaching Mode-based on the Robot Teaching in Middle and Primary Schools [J], China Educational Technology, 2015(2): 112-117.

[3] Zhang Guangyu, the Applied Research on the Flipped Classroom Teaching Model Supported by Micro-course[J], Learning Weekly, 2016(32): 29-30.

[4] Zhang Lijun, the Exploration on the Fundamentals of Computer Application in Colleges Based on the Blended Learning [J], Chinese Management Informationization, 2016(16): 235-236.

[5] Wan Fang, the Applied Research on the Micro-project Learning in the Fundamentals of Computer Application in Higher Vocational Education[J], Chinese Management Informationization, 2016(16): 247248.

[6] Wu Renhua, the Exploration on the Professional Cluster construction of the Applied Undergraduate [J], the Higher Engineering Education Study, 2016(16): 98-102 